\title{
Distribution and Characterization of Actinomycetes in Mangrove Habitats (Red Sea, Egypt) with Special Emphasis on Streptomyces mutabilis M3MT483919
}

\author{
Moaz M. Hamed (D), Mohamed A.A. Abdrabo (D), Nayer M. Fahmy (D), \\ Lamis S. Abdelfattah $\left(\mathbb{D}\right.$, Mahmoud S. Kelany $\mathbb{D}^{D}$, Hala H. Abd-El latif $\mathbb{D}^{\text {, }}$ \\ Gehan M. Abou El ela, Hanan M Abd-Elnaby (D) and Sahar W.M. Hassan* \\ Marine Microbiology Laboratory, Marine Environmental Division, National Institute of Oceanography and \\ Fisheries, Egypt.
}

\begin{abstract}
Ten sediment samples were gathered from several geographical locations around mangrove habitat, Red Sea coast, Egypt, during summer 2019. Actinobacteria are widespread in most mangrove soil samples. The average actinomycetes counts in sediment samples were ranged from 4 to $15 \mathrm{CFUg}^{-1}$, also physico-chemical characters for soil samples were determined. Statistical analysis was applied to assess if the geographical location and physico-chemical characters influenced the communities of actinomycetes. A total of $\mathbf{1 0}$ actinomycetes were isolated and characterized physiologically and biochemically. The antimicrobial activities of different actinomycetes isolates were assessed. Isolate M3 was chosen as the most promising isolate with broad antagonistic activity against Bacillus subtilis ATCC 6633, Escherichia coli ATCC 19404, Staphylococcus aureus ATCC6538, Pseudomonas aeruginosa ATCC 9027, and Candida albicans ATCC 10231 with inhibition zones ranged from $12.0 \pm 0.9$ to $20.0 \pm 1.9 \mathrm{~mm}$. Genotypic characterization of isolate $\mathrm{M} 3$ was made using $16 \mathrm{~S}$ rDNA sequence analysis and identified as Streptomyces mutabilis M3 with accession number MT483919. This strain exhibited anticancer activity against breast cancer cell line (Mcf7), liver cancer cell line (HepG2) and colon cancer cell line (HCT116) and the IC50 values were 324.77, 333.71 and 354.46, respectively. Streptomyces mutabilis M3 MT483919 had high bio-flocculating activity for seawater treatment, and the recovery of the samples ranged between 71.97 and $76.05 \%$. The crude extract of Streptomyces mutabilis MT483919 M3 was analyzed by Fourier transform infrared spectrum (FT-IR) and Gas chromatography-mass spectrometry (GC-MS).

Keywords: Mangrove Habitats, Streptomyces mutabilis, M3
\end{abstract}

*Correspondence: saharwefky@yahoo.com

(Received: November 12, 2020; accepted: December 28, 2020)

Citation: Hamed MM, Abdrabo MAA, Fahmy NM, et al. Distribution and Characterization of Actinomycetes in Mangrove Habitats (Red Sea, Egypt) with Special Emphasis on Streptomyces mutabilis M3MT483919. J Pure Appl Microbiol. 2021;15(1):246-261. doi: 10.22207/JPAM.15.1.19

(C) The Author(s) 2021. Open Access. This article is distributed under the terms of the Creative Commons Attribution 4.0 International License which permits unrestricted use, sharing, distribution, and reproduction in any medium, provided you give appropriate credit to the original author(s) and the source, provide a link to the Creative Commons license, and indicate if changes were made. 


\section{INTRODUCTION}

Mangrove is a fertile and underexploited ecosystem with unlimited diversity of microbes for the detection of new and chemically diverse antimicrobial compounds ${ }^{1}$. Mangrove swamps are found in the world's tropical areas which are sheltered from wave action and are usually highly sedimented. The forest of mangroves is a fringing population of shallow sandy or muddy areas, extending from the highest mark to the intertidal and subtidal regions ${ }^{2}$. Mangrove ecosystems are often inadequately explored but provide good resources to isolate novel actinomycetes ${ }^{3}$. Mangroves occur along the Red Sea coast and Sinai Peninsula in Egypt. At Gonah, about $25 \mathrm{~km}$ north of Hurghada, is the northernmost locality of mangroves along the Red Sea continental coast. From Hurghada to the Sudanese frontier, mangroves are prominent in protected bays, lagoons, beaches, dry wadis mouth and lacunae filled with sediments ${ }^{4}$. It is understood that climate fluctuations such as changes in salinity and tidal gradient are continuously encountered in the mangrove habitats. Forests of mangrove are home to numerous animals and plants 5 . Rather, these unexpected changes in the environment could be the motive force for the establishment of diversity of microbes and the variation in metabolic pathways that could create certain inimitable microbial properties ${ }^{6}$. Therore, the study of mangrove actinomycetes can offer a better view of discovering unique isolates, which lead to the discovery of respected antimicrobial compounds ${ }^{7,8}$. Scientistis are still studying the community diversity in phylum actinomycetes from diverse nations and environments, due to their ecological significance and biotechnological benefits ${ }^{9}$. Recent studies show that marine actinomycetes isolated from Red Sea mangrove forests can be a appreciated source for antibacterial, antioxidants and anticancer agents. The target of this study was to evaluate biodiversity and elucidate mangrove actinomycetes bioactivity along the mangrove area $17 \mathrm{~km}$ south of the Egyptian Red Sea coast town of Safaga city, and investigate the characterization of Streptomyces mutabilis M3 isolated from mangrove habitats and their antimicrobial and bio-loculation activities.

\section{MATERIALS AND METHODS \\ Gathering of Mangrove Soil Samples}

Ten soil samples were gathered from the selected sites in mangrove location during summer 2019. The mangrove area situated $17 \mathrm{~km}$ south of Safaga city on the western side of the Red Sea coast at the intersection of latitude $26^{\circ} 36^{\prime} 53^{\prime \prime}-$ $26^{\circ} 37^{\prime} 07^{\prime \prime} \mathrm{N}$ and longitudes $34^{\circ} 00^{\prime} 46^{\prime \prime}-34^{\circ} 00^{\prime} 27^{\prime \prime} \mathrm{E}$ (Fig. 1). The samples locations and information are itemized in Table 1. The collected samples have been filled into sterilized packets and transported to the laboratory as soon as possible. All the mangrove forest areas studied are characterized by a single community dominated by Avicennia marina $^{10}$.

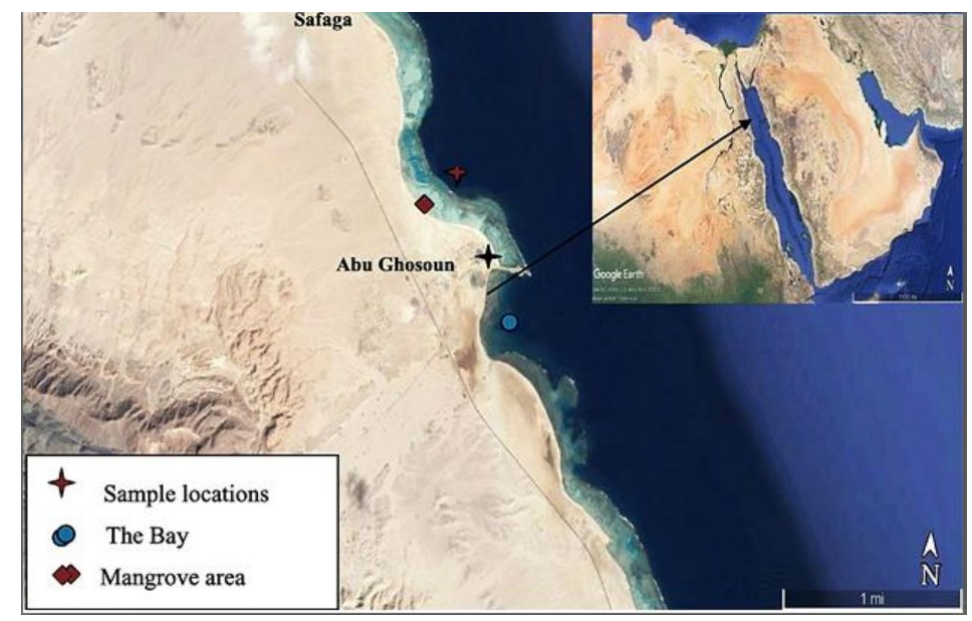

Fig. 1. The study area and sampling site 


\section{Physico-chemical characteristics for samples}

Physical parameters such as temperature, $\mathrm{pH}$ and salinity were examined for the soil samples using the 556 Handheld Multiparameter Instrument. Chemical characteristics such as dissolved oxygen ${ }^{12}$, dissolved nitrate ${ }^{13}$, dissolved nitrite, dissolved phosphate and dissolved ammonia ${ }^{14}$ were also measured using standard methods.

\section{Isolation and purification of actinomycetes}

The initial treatment of mangrove soil samples was based on the $60^{\circ} \mathrm{C}$ dry wet method in a combination of seawater (1: $1 \mathrm{v} / \mathrm{v})$ for 15 minutes to reduce the number of unicellular bacteria ${ }^{15}$. Soil suspension up to $1 \mathrm{ml}$ was inoculated in Starch Casein Agar (SCA) medium (g/l: Starch, 10; Casein, 0.3; $\mathrm{KNO}_{3}, 2 ; \mathrm{K}_{2} \mathrm{HPO}_{4}$, 2; $\mathrm{MgSO}_{4} .7 \mathrm{H}_{2} \mathrm{O}, 0.05 ; \mathrm{FeSO}_{4} .7 \mathrm{H} 2 \mathrm{O}, 0.01 ; \mathrm{CaCO}_{3}$, 0.02 ; Agar, 20) supplemented by nalidixic acid (20 $\mathrm{mg} / \mathrm{l})$, cycloheximide $(50 \mathrm{mg} / \mathrm{l})$, and potassium dichromate $(50 \mathrm{mg} / \mathrm{l})$ to prevent the growth of Gram-negative bacteria and fungi ${ }^{1}$. After incubation at $32^{\circ} \mathrm{C}$ for 7-30 days. Colony Forming Unit (CFU) was estimated, colonies were selected up and streaked on SCA medium. Pure cultures have been maintained on SCA agar slants at $4^{\circ} \mathrm{C}$ for numerous weeks and have also been wellmaintained in suspensions $(20 \%, v / v)$ of glycerol at $-80^{\circ} \mathrm{C}$.

\section{Characterization of actinomycetes isolates}

Out of 65 actinomycetes isolates, 10 isolates were selected based on their color variability and pigmentation on starch casein agar medium and incubation $7-14$ days at $32^{\circ} \mathrm{C}$. Morphology of colonies of the isolates was detected regarding color of substrate and aerial mycelia in addition to branching according to ${ }^{16}$. Cultural characteristics (growth, aerial and substratum mycelium coloration, soluble pigment formation) have been tested in seven different media including Yeast extract malt extract agar ${ }^{17}$, Inorganic salts starch agar ${ }^{18}$, Czapex Dox agar ${ }^{19}$, Krassilnikov agar ${ }^{20}$, Oat meal agar ${ }^{21}$ and Starch nitrate agar $^{22}$.

\section{Biochemical characterization}

Biochemical tests generally used are hydrolysis of starch, casein, urea and gelatin. In addition to indole production test, methyl red test, Voges-prauskauer test, nitrate reduction, $\mathrm{H}_{2} \mathrm{~S}$ production, catalase, oxidase and gelatin liquefaction tests ${ }^{23}$

\section{Physiological characterization}

Physiological characterization, such as optimum $\mathrm{pH}(5-9)$, temperature $\left(15-50^{\circ} \mathrm{C}\right)$ and salinity ( $\mathrm{NaCl} 0-13 \%)$ were also tested. Use of carbon sources such as sucrose, fructose, glucose, starch, dextrose and maltose. Also some sources of nitrogen such as L-tyrosine and L-arginine were tested ${ }^{24}$.

\section{Fermentation}

The chosen actinomycetes isolates were then cultured on soluble Starch Casein media with $\mathrm{pH}$ of (7.5). The selected actinomycetes were inoculated in the prepared medium and retained at room temperature for 4-7 days in a rotary shaker. The cultures were then centrifuged for $15 \mathrm{~min}$ at $8000 \mathrm{rpm}$, and the supernatant was obtained for extra studies ${ }^{25}$.

Antimicrobial activity

The bacterial pathogens used in the

Table 1. Locations and Information of soil samples

\begin{tabular}{|c|c|c|c|}
\hline $\begin{array}{l}\text { Sample } \\
\text { number }\end{array}$ & Location & The characteristic of soil & $\begin{array}{c}\text { Sampling depth } \\
\text { under surface }(\mathrm{cm})\end{array}$ \\
\hline
\end{tabular}

\begin{tabular}{llcc}
\hline 1 & $26^{\circ} 36^{\prime} 53^{\prime \prime} \mathrm{N}-34^{\circ} 00^{\prime} 49^{\prime \prime} \mathrm{E}$ & Rhizosphere soil of Avicennia marina & 5 \\
2 & $26^{\circ} 36^{\prime} 54^{\prime \prime} \mathrm{N}-34^{\circ} 00^{\prime} 46^{\prime \prime} \mathrm{E}$ & Rhizosphere soil of Avicennia marina & 5 \\
3 & $26^{\circ} 36^{\prime} 55^{\prime \prime} \mathrm{N}-34^{\circ} 00^{\prime} 45^{\prime \prime} \mathrm{E}$ & Rhizosphere soil of Avicennia marina & 10 \\
4 & $26^{\circ} 36^{\prime} 56^{\prime \prime} \mathrm{N}-34^{\circ} 00^{\prime} 43^{\prime \prime} \mathrm{E}$ & Muddy soil & 5 \\
5 & $26^{\circ} 36^{\prime} 57^{\prime \prime} \mathrm{N}-34^{\circ} 00^{\prime} 42^{\prime \prime} \mathrm{E}$ & Muddy soil & 10 \\
6 & $26^{\circ} 36^{\prime} 58^{\prime \prime} \mathrm{N}-34^{\circ} 00^{\prime} 40^{\prime \prime} \mathrm{E}$ & Sandy soil & 10 \\
7 & $26^{\circ} 37^{\prime} 01^{\prime \prime} \mathrm{N}-34^{\circ} 00^{\prime} 35^{\prime \prime} \mathrm{E}$ & Sandy soil & 10 \\
8 & $26^{\circ} 37^{\prime} 04^{\prime \prime} \mathrm{N}-34^{\circ} 00^{\prime} 30^{\prime \prime} \mathrm{E}$ & Rhizosphere soil of Avicennia marina & 10 \\
9 & $26^{\circ} 37^{\prime} 05^{\prime \prime} \mathrm{N}-34^{\circ} 00^{\prime} 30^{\prime \prime} \mathrm{E}$ & Muddy soil & 10 \\
10 & $26^{\circ} 37^{\prime} 06^{\prime \prime} \mathrm{N}-34^{\circ} 00^{\prime} 30^{\prime \prime} \mathrm{E}$ & Muddy soil & 10
\end{tabular}


present study were Staphylococcus aureus ATCC6538, Bacillus subtilis ATCC 6633, Pseudomonas aeruginosa ATCC 9027, Salmonella typhimurium ATCC 14028, Escherichia coli ATCC 19404 and Candida albicans ATCC 10231. The pathogenic strains were kindly gained from The National Institute of Oceanography and Fisheries (NIOF), Egypt. The antibacterial activities of the actinomycetes' supernatant was evaluated using well cut diffusion technique. The pathogens were inoculated by using sterilized cotton swabs on Mueller Hinton agar. Next, wells were bored using a well-borer sterilized micro tip and $100 \mu$ l of crude extracts were added into the wells. The plates were incubated overnight at $37^{\circ} \mathrm{C}$. Duplicate was prepared for each set. After incubation, positive result was taken as the radius in $(\mathrm{mm})$ of clear inhibition zone around each well ${ }^{26}$.

\section{Solvent extraction}

The bioactive metabolites (s) in the crude extract was extracted using ethyl acetate. The extraction was done by mixing 1:1 ratio of the crude extract and the solvent in separate funnel and was vigorously shaken for $1 \mathrm{~h}$ then left to stand for $24 \mathrm{~h}$. Further extraction of the organic layer was done for additional studies ${ }^{27}$.

\section{Molecular identification of actinomycetes}

Genomic DNA of representative selected actinomycetes isolate were extracted using Gene Jet genomic DNA purification Kit (Fermenats) using the manufacturer's protocol. The 16S rRNA gene PCR amplification was performed using the following primers: 27F: (5' AGAGTTTGATCCTGGCTCTCAG-3') and 1492R (5'GGTTACCTTGTTACGACTT-3') ${ }^{28}$. The final volume of PCR reactions was $50 \mu$ l consisting of 200 ng DNA templates, $25 \mu \mathrm{l}$ Maxima Hot Start PCR Master Mix (2Xs) and 0,4 $\mu \mathrm{M}$ primers under the following conditions: initial $94^{\circ}$ denaturation for 5 minutes followed by $30 \mathrm{~s}$ at $94^{\circ} \mathrm{C}$ cycles for $30 \mathrm{~s}, 60 \mathrm{~s}$ at $55^{\circ} \mathrm{C}$ and 4 minutes extension phase at $72^{\circ} \mathrm{C}$ and 10 minutes extension point. PCR reactions were conducted in a $50 \mu$ l final volume. The amplification products were confirmed using $1 \%$ agarose gel and sent to GATC Biotech Company, German for purification and sequencing. The GenBank BLASTn search tool (http://www. ncbi.mlm.nih.gov) was used to analyze the partial nucleotide selected isolate sequences. This supported the isolate closest phylogenetic neighbors. The GenBank submitted the following accessionMT483919number to partial 16S rRNA gene sequence of actinomycetes isolated. The Sequence was then aligned by the software Clustal W, and the phylogenetic tree by molecular Evolutionary genetic analysis (MEGA version 6.0) was extracted from a neighboring joining algorithm.

\section{Anticancer activity}

The cytotoxic effect of Streptomyces mutabilis M3. extract on breast cancer cell line (Mcf7), liver cancer cell line (HepG2) and colon cancer cell line (HCT116)- was investigated using 3-(4,5-dimethylthiazol-2-yl)-2,5diphenyltetrazolium bromide (MTT). Cells were grown in 96-well plate at density of $1 \times 10^{5} \mathrm{cell} / \mathrm{ml}$ and incubated for $24 \mathrm{~h}$ at $37^{\circ} \mathrm{C}$ to form monolayer sheets. The growth medium was decanted and the cells were washed twice and $0.1 \mathrm{~mL}$ of RPMI containing different concentration (31.25 to $1000 \mathrm{mg} / \mathrm{ml}$ ) of the extract was inoculated in each well. Control wells were treated with the medium containing the solvent (DMSO) without sample. After incubation at $37^{\circ} \mathrm{C}$ with $5 \% \mathrm{CO}_{2}$ for $72 \mathrm{~h}, 20 \mathrm{ML}$ of MTT solution (5mg/ml in PBS) was added to each well, mixed thoroughly and further incubated for 1-5 h. the medium was removed and Formazan was dissolved in $100 \mathrm{Ml}$ of DMSO. The amount of MTT-formazan was determined at $570 \mathrm{~nm}$ absorbance with $650 \mathrm{~nm}$ as reference wavelength ${ }^{29-31}$.

\section{Bio-flocculation activity}

A protocol of Kurane ${ }^{32}$ is used to study the bio-flocculating activity, Briefly, $2 \mathrm{ml}$ of the culture broth, $5 \mathrm{ml}$ of $\mathrm{CaCl}_{2}(1 \%, \mathrm{w} / \mathrm{v})$, and $93 \mathrm{ml}$ of kaolin ( $5 \mathrm{gl}^{-1}$ distilled water) suspension were added in a 200- $\mathrm{ml}$ beaker and stirred at $180 \mathrm{r}$ $\mathrm{min}^{-1}$ for $1.5 \mathrm{~min}$ and at $80 \mathrm{r} \mathrm{min}^{-1}$ for $3 \mathrm{~min}$ with a vortex mixer (QL- 861, Shanghai Jingmi Instrument Co., Ltd., China) and then kept still for $10 \mathrm{~min}$. A sample was withdrawn $(1 \mathrm{~cm}$ below the surface of clay suspension) to measure optical densities (OD). A control experiment without bio-flocculant was carried prepared. The bio-flocculation activity was determined relying on OD for the suspension of clay using spectrophotometer at $550 \mathrm{~nm}$. The flocculating efficiency was calculated using the following equation: Bio-flocculation activity $=(B-$ $A) / B \times 100$. Where; $A$ and $B$ are ODs of the culture sample and the control, respectively. 


\section{Fourier transform infrared (FT-IR) spectral analysis}

Functional groups of the extracted compound was determined using FT-IR spectrometer in the scan range of 450 to 4000 $\mathrm{cm}^{-1}$. AV500 FT-NMR spectrometer was used for H1NMR analysis to recognize the functional groups exist in the compound ${ }^{33}$.

\section{Gas chromatography-mass spectrometry (GC-MS) analysis}

The GC-MS (Jeol GCMATE II GC-MS) analysis was carried out and the device is attached to a component of the mass spectrum (MS) system and Agilent Technologies 6890 NGC system for gas chromatography.HP5 (50 m to $0.25 \mathrm{~mm}$ ) of GC column was used. For a period of 20 minutes the temperature of the column was maintained at $100^{\circ} \mathrm{C}, 3 \mathrm{~min}$ was maintained at $235^{\circ} \mathrm{C}$ and the injector temperature was $240^{\circ} \mathrm{C}$. The results of the MS analysis match the library and identify the closest match ${ }^{34}$.

\section{Statistical analysis}

Significant analysis, canonical correspondence analysis (CCA) was determined using XLSTAT, 2014 to find the association between three sets of variables in 1000 permutations and a $5 \%$ significance level. Actinomycetes count was the first variable, distribution of sites was the second variable and physico-chemical parameters were the third variable. Principle coordinate analysis (PCO) was determined by XLSTAT, 2014 for distributing the correlated sites according to actinomycetes communities and physico-chemical parameters ${ }^{35}$.

\section{RESULTS AND DISCUSSION}

Distribution of marine actinomycetes in mangrove soil samples

The average actinomycetes counts (CFU $\mathrm{g}^{-1}$ ) were estimated during the summer of 2019 in soil samples from mangrove area, Red Sea coast, Egypt (Fig. 2). In general, the sample number

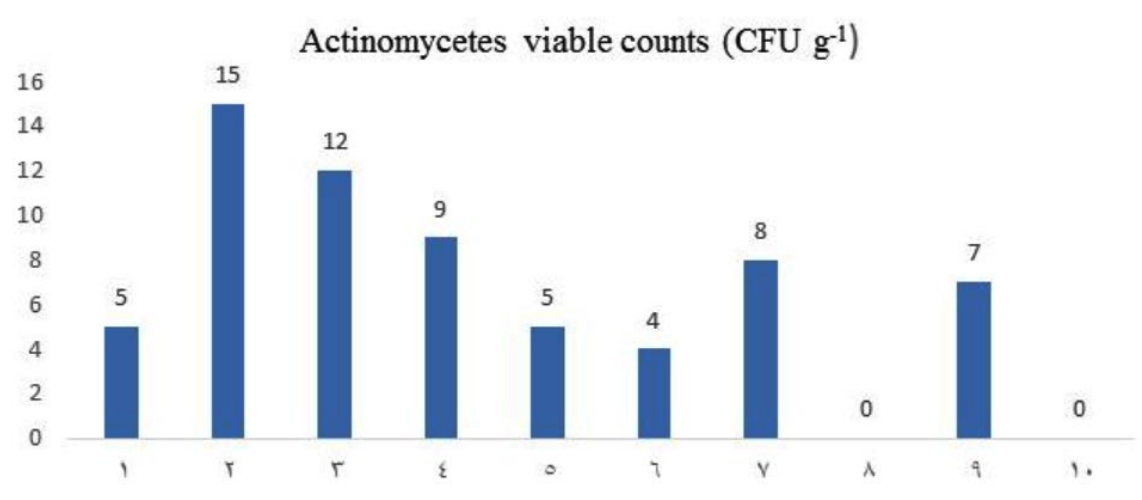

Fig. 2. Actinomycetes viable counts (CFU g-1) of mangrove soil samples during summer 2019

Table 2. Physicochemical characters of soil samples collected from mangrove area during Summer 2019

\begin{tabular}{|c|c|c|c|c|c|c|c|c|}
\hline \multirow[b]{2}{*}{$\begin{array}{l}\text { Sample } \\
\text { number }\end{array}$} & \multicolumn{8}{|c|}{ Physical-chemical parameters } \\
\hline & $\begin{array}{c}\text { Temp. } \\
\left({ }^{\circ} \mathrm{C}\right)\end{array}$ & $\mathrm{pH}$ & $\begin{array}{c}\text { Salinity } \\
(\% \text { ) }\end{array}$ & $\begin{array}{c}\mathrm{DO} \\
\left(\mathrm{mgl}^{-1}\right)\end{array}$ & $\begin{array}{l}\mathrm{NO}_{3} \\
(\mu \mathrm{M})\end{array}$ & $\begin{array}{l}\mathrm{NO}_{2} \\
(\mu \mathrm{M})\end{array}$ & $\begin{array}{l}\mathrm{NH}_{4} \\
(\mu \mathrm{M})\end{array}$ & $\begin{array}{l}\mathrm{PO}_{4} \\
(\mu \mathrm{M})\end{array}$ \\
\hline 1 & 32.1 & 8.75 & 42.1 & 6.3 & 0.5 & 0.02 & 3.06 & 0.05 \\
\hline 2 & 32.2 & 8.71 & 42.1 & 6.5 & 0.3 & 0.08 & 2.73 & 0.04 \\
\hline 3 & 32.3 & 8.81 & 42.0 & 6.5 & 0.3 & 0.07 & 2.84 & 0.04 \\
\hline 4 & 32.1 & 8.69 & 42.2 & 6.8 & 0.4 & 0.07 & 2.87 & 0.05 \\
\hline 5 & 32.4 & 8.77 & 42.0 & 6.5 & 0.3 & 0.08 & 2.88 & 0.04 \\
\hline 6 & 32.4 & 8.78 & 42.2 & 6.6 & 0.5 & 0.09 & 2.67 & 0.08 \\
\hline 7 & 32.5 & 8.72 & 42.1 & 6.4 & 0.4 & 0.04 & 2.94 & 0.04 \\
\hline 8 & 32.3 & 8.78 & 42.0 & 6.5 & 0.9 & 0.08 & 3.09 & 0.08 \\
\hline 9 & 32.1 & 8.69 & 42.1 & 6.5 & 0.5 & 0.06 & 2.99 & 0.04 \\
\hline 10 & 32.2 & 8.73 & 42.2 & 6.1 & 0.7 & 0.09 & 3.13 & 0.05 \\
\hline
\end{tabular}


2 showed higher counts of actinomycetes (15 CFU g-1), whereas the lowest counts (4 CFU g $\left.{ }^{-1}\right)$ reported in sample number 6 . Actinobacteria are widespread in all mangrove environments ${ }^{1,36,37}$. Several previous studies reports the occurrences of actinomycetes in different mangrove habitats from various geographical locations around the world ${ }^{38}$. Previous study showed 85 actinobacterial isolates from 60 sediment samples collected from mangrove rhizosphere on the Egyptian Red Sea coast $^{39}$.

\section{Physicochemical characters of soil samples}

The variations in environmental factors (temperature, $\mathrm{pH}$, salinity, dissolved oxygen, dissolved nitrate, dissolved nitrite, dissolved phosphate and dissolved ammonia) of soil samples lead to variations in marine actinomycetes density (Table 2). Isik ${ }^{40}$ and his team, reported that, actinomycetes present in any sample would be significantly influenced by geographical location and environmental factors.

\section{Canonical correspondence analysis and principle coordinate analysis}

Influence of physico-chemical parameters on actinomycetes community was assessed using Canonical correspondence analysis (CCA). The community of actinomycetes achieved $88.26 \%$ similarity with physico-chemical parameters and stations origin diversity. Based on Fig. (3A), actinomycetes communities influenced by $\mathrm{pH}$, temperature, nitrate, nitrite and dissolved oxygen. At the station level, samples 1, 3, 4 and 7 are positively stimulated by $\mathrm{pH}$. Samples 5 , 8 and 9 were positively stimulated by nitrate. Samples 2 and 6 were positively stimulated by temperature, salinity, phosphate and dissolved oxygen. Actinomycetes are act as neutrophils in marine ecosystem, so $\mathrm{pH}$ is very important

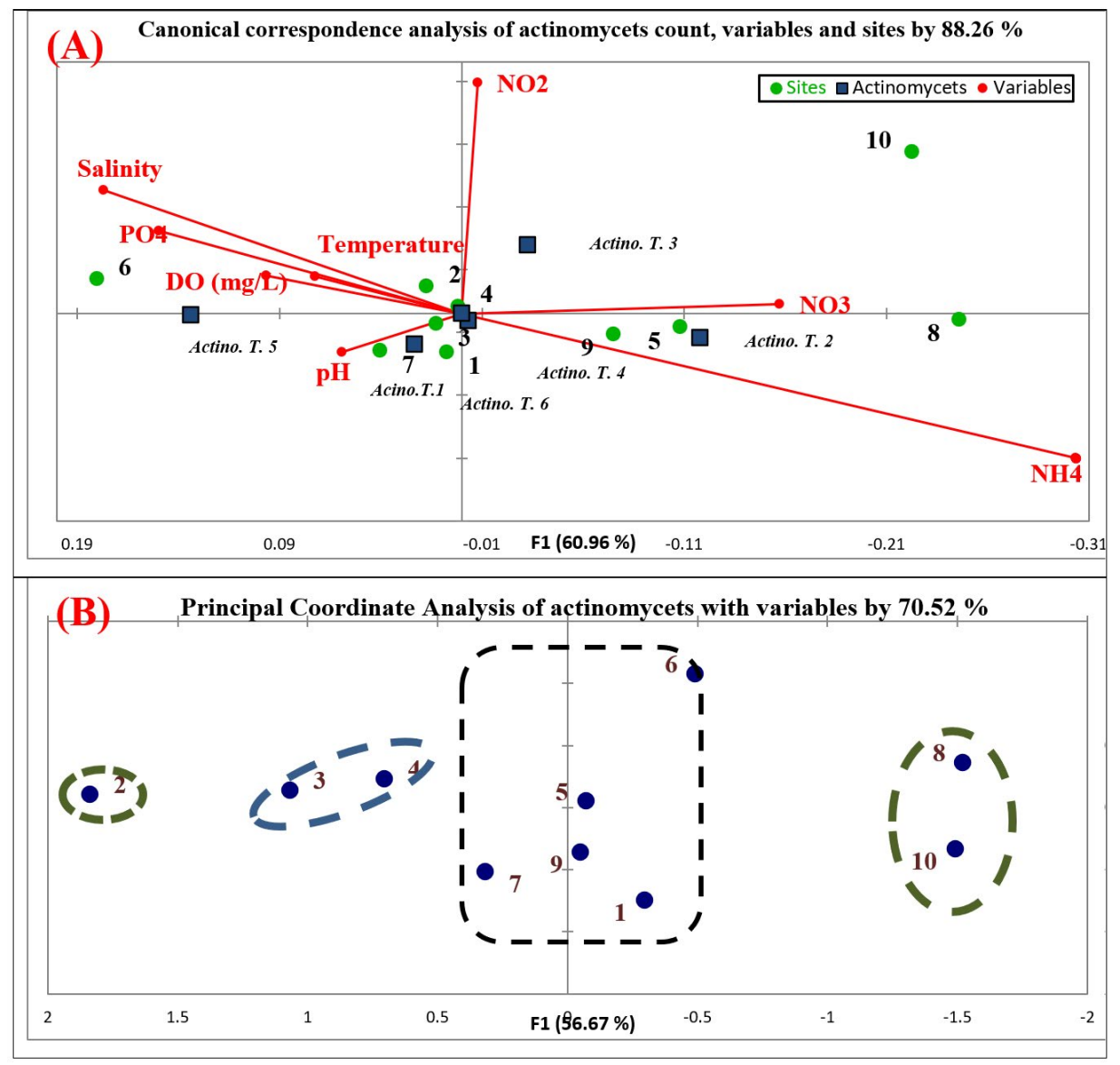

Fig. 3. Statistical analysis of actinomycetes, sites and physico-chemical parameters; (A)Biplot of canonical correspondence analysis (ccA); (B) Biplot of principle coordinate analysis (PCoA). 
factor for enumeration, distribution and activity of these microorganisms ${ }^{41}$. In the present study, samples were alkaline in all the stations and this leading to increase the actinomycetes count. The dominant $\mathrm{pH}$ for growing actinomycetes is neutral $\mathrm{pH} 7^{42}$. This is different in these studies which all actinomycetes $\mathrm{pH}$ ranged from 8-9 $\mathrm{pH}$. Beside $\mathrm{pH}$, temperature is second most important factor for microbial growth. Actinomycetes are mesophilic and growing in temperature range (25 $-30^{\circ} \mathrm{C}$ ). The range of temperature was relatively higher in the current study and the influence of temperature on distribution of the actinomycetes in the present study was observed. Similar results were reported by Abd-Elnaby et al. ${ }^{43}$. Nitrate and nitrite of different stations is different, and this influences the communities of actinomycetes. $\mathrm{NO}_{2}$ is relatively unsteady and can be quickly oxidized to $\mathrm{NO}_{3}$. Higher concentrations of $\mathrm{NO}_{2}$ can arise in the distribution system when chlorination is used, but the occurrence is always irregular. The concentration of $\mathrm{NO}_{3}$ and $\mathrm{NO}_{2}$ in different sites is relatively in acceptable range and they affected positively on growth of actinomycetes communities $^{44}$. The increasing of water dissolved oxygen is indicator for microbial decomposition of organic matters. So, the recording of actinomycetes in samples is influenced by amount of organic matter ${ }^{45}$. This is clearly summarized by dissolved oxygen range in study area. The second statistical analysis (principle coordinate analysis) illustrated the correlation between samples and different parameters with actinomycetes count (Fig. 3-B). Samples 1, 5, 6, 7 and 9 were correlated by

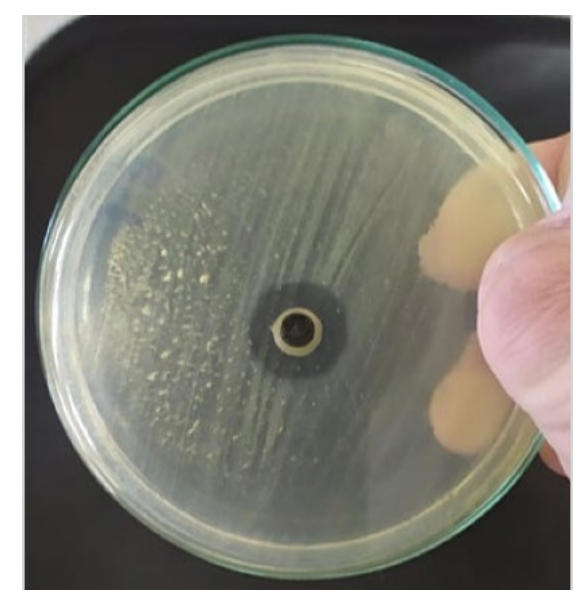

Fig. 4. Inhibition zone diameter of isolate M3 supernatant against Pseudomonas aeruginosa ATCC 9027
$20 \%$. The nature of soil in these sites is different, but they are similar in influencing by different variables. On the other hand, samples 3, 4, 8 and 10 were correlated by $40 \%$. Finally, sample 2 is not correlated with any other sites upon correlation of different parameters. This refers to the origin of parameters in this site.

\section{Morphological, biochemical and physiological characterization}

Of the total marine actinomycetes isolates obtained, ten actinobacterial isolates were selected and coded as (M1, M2, M3, M4, M5, M6, M7, M8, M9 and M10). They were selected on the basis of leathery powdery growth, color variability and pigmentation. Table 3 reported the cultures and characteristics of marine actinomycetes isolates. Aerial mass color of substrate mycelium was determined after 7 to 10 days. All marine actinomycetes isolates grown well on all tested media except three isolates (M6, M8 and M9) could not grow on starch agar and inorganic salts. The substrate mycelium of five isolates was yellow, three isolates had cream color and two isolates had Pink. Most of them had white or gray aerial mycelium. Two isolates produce beige diffusible pigments, only one produce violet and other one produce dark brown. All isolates grew at $25-30^{\circ} \mathrm{C}$ and the majority grew at $35^{\circ} \mathrm{C}, \mathrm{pH}$ 7-9. Starch, lactose, fructose, dextrose, glucose and sucrose were utilized by all strains as carbon sources, the majority utilized maltose. Most of them utilized I-arginine and I-tyrosine. All isolates produced catalase and the majority produced gelatinase. Indeed, characterization studies help to explain biological, ecological, physiological and biochemical characteristics. The characterization is as important as an analysis of the existence of these microbes ${ }^{46}$. This is of utmost importance for understanding the basic physiology of the marine isolates of actinomycete to be biochemically and physiologically characterized ${ }^{47}$.

\section{Antimicrobial activities}

Assessment of the antimicrobial activity of the cell-free supernatant of the selected ten marine actinomycetes isolates using the agar well diffusion method against tested pathogens was demonstrated as in Table 4. Significantly, the actinomycetes isolate $M 3$ showed the highest inhibition zones $12.0 \pm 0.9,20.0 \pm 0.7$, 
Table 3. Phenotypic characteristics of actinomycetes isolates

\begin{tabular}{|c|c|c|c|c|c|c|c|c|c|c|}
\hline \multirow[t]{2}{*}{ Character } & \multicolumn{10}{|c|}{ Actinomycetes isolates } \\
\hline & M1 & $\mathrm{M} 2$ & M3 & M4 & M5 & M6 & M7 & M8 & M9 & M10 \\
\hline \multicolumn{11}{|l|}{ Growth on } \\
\hline Yeast extract malt extract agar & + & + & + & + & + & + & + & + & + & + \\
\hline Inorganic saltsstarch agar & + & + & + & + & + & - & + & - & - & + \\
\hline Czapex Dox agar & + & + & + & + & + & + & + & + & + & + \\
\hline Krassilnikov agar & + & + & + & + & + & + & + & + & + & + \\
\hline Oat meal agar & + & + & + & + & + & + & + & + & + & + \\
\hline Starch nitrate agar & + & + & + & + & + & + & + & + & + & + \\
\hline Starch casein agar & + & + & + & + & + & + & + & + & + & + \\
\hline \multicolumn{11}{|l|}{ Substrate mycelium } \\
\hline Yellow & - & - & + & + & - & - & - & + & + & + \\
\hline Cream & + & - & - & - & - & + & + & - & - & - \\
\hline Pink & - & + & - & - & + & - & - & - & - & - \\
\hline \multicolumn{11}{|l|}{ Aerial mycelium } \\
\hline White & + & + & - & - & - & - & - & + & + & + \\
\hline Cream & - & - & - & - & - & - & - & - & - & - \\
\hline Gray & - & - & + & + & - & + & - & - & - & - \\
\hline Yellow & - & - & - & - & - & - & + & - & - & - \\
\hline Pink & - & - & - & - & + & - & - & - & - & - \\
\hline Brown & - & - & - & - & - & - & - & - & - & - \\
\hline \multicolumn{11}{|l|}{ Diffusible pigments } \\
\hline Beige & - & - & + & - & - & - & + & - & - & - \\
\hline Yellow & - & - & - & - & - & - & - & - & - & - \\
\hline Violet & - & + & - & - & - & - & - & - & - & - \\
\hline Dark brown & - & - & - & + & - & - & - & - & - & - \\
\hline \multicolumn{11}{|l|}{ Growth at $\left({ }^{\circ} \mathrm{C}\right)$} \\
\hline $15-25$ & + & + & + & + & + & + & + & + & + & + \\
\hline $30-35$ & + & + & - & + & + & + & + & + & - & + \\
\hline $40-50$ & - & - & - & - & - & - & - & - & - & - \\
\hline \multicolumn{11}{|l|}{ Growth at pH } \\
\hline $5-6$ & - & - & - & - & + & - & - & - & - & - \\
\hline $7-9$ & + & + & + & + & + & + & + & + & + & + \\
\hline \multicolumn{11}{|l|}{ Utilization of } \\
\hline Starch & + & + & + & + & + & + & + & + & + & + \\
\hline Lactose & + & + & + & + & + & + & + & + & + & + \\
\hline Fructose & + & + & + & + & + & + & + & + & + & + \\
\hline Dextrose & + & + & + & + & + & + & + & + & + & + \\
\hline Maltose & - & + & - & + & + & + & + & + & - & + \\
\hline Glucose & + & + & + & + & + & + & + & + & + & + \\
\hline Sucrose & + & + & + & + & + & + & + & + & + & + \\
\hline L-arginine & + & - & + & + & - & - & + & + & - & - \\
\hline L-tyrosine & + & - & + & + & + & - & + & + & + & - \\
\hline \multicolumn{11}{|l|}{ Growth in presence of $\mathrm{NaCl}$ (\%) } \\
\hline $0-4$ & - & - & - & - & - & + & - & - & + & - \\
\hline $7-10$ & + & + & + & + & + & + & + & + & + & + \\
\hline 13 & - & - & - & - & - & - & - & - & - & - \\
\hline \multicolumn{11}{|l|}{ Biochemical testes } \\
\hline Casein hydrolysis & + & + & + & + & + & + & + & + & + & + \\
\hline Urea hydrolysis & + & - & + & - & - & - & - & + & - & - \\
\hline Gelatin hydrolysis & + & + & + & + & - & + & - & + & - & - \\
\hline Indole production & - & - & - & - & - & - & - & - & + & - \\
\hline Methyl red & - & - & - & - & - & - & - & - & - & - \\
\hline Voges prauskauer & - & - & - & - & - & - & - & - & - & - \\
\hline $\mathrm{H}_{2} \mathrm{~S}$ production & - & - & - & - & - & - & - & - & - & - \\
\hline Catalase production & + & + & + & + & + & + & + & + & + & + \\
\hline
\end{tabular}


$18.0 \pm 0.9,20.0 \pm 1.9$ and $12.0 \pm 1.2 \mathrm{~mm}$ against Staphylococcus aureus ATCC6538, Bacillus subtilis ATCC 6633, Pseudomonas aeruginosa ATCC 9027, Escherichia coli ATCC 19404 and Candida albicans ATCC 10231, respectively (Fig. 4). Actinomycetes isolate M5 showed $14.0 \pm 1.6,12.0 \pm 0.5,16.0 \pm$ 1.2 and $20.0 \pm 0.8 \mathrm{~mm}$ against Staphylococcus aureus ATCC6538, Pseudomonas aeruginosa ATCC 9027, Salmonella typhimurium ATCC 14028 and Escherichia coli ATCC 19404, respectively. On the other hand, isolate M9 affected on three pathogens only, isolates $\mathrm{M} 1, \mathrm{M} 2, \mathrm{M} 4, \mathrm{M} 6$, and
M8 affected on two microbial pathogens, finally isolates M7 and M10 affected on one pathogen.

Mangrove microorganisms, in particular actinobacteria, were reported to be capable of producing structurally unique bioactive natural products ${ }^{1,36}$. Previous study reported the presence of bioactive compounds (particularly antibiotics) in actinomycetes inhabiting the mangrove environment ${ }^{38,48}$. For examples, crude extracts of actinomycetes isolates (A5, A71 and A70) exhibited strong antimicrobial activity ${ }^{39}$ Streptomyces $\mathrm{sp}$. isolate EGY2 showed highest antimicrobial and

Table 4. Antimicrobial activity of actinomycetes isolates against different pathogens

\begin{tabular}{lcccccc}
\hline \multicolumn{7}{c}{ Inhibition zone $(\mathrm{mm})$} \\
\hline Isolates & S. aureus & B. subtilis & P. aeruginosa & S. typhimurium & E. coli & C. albicans \\
\hline M1 & $10.0 \pm 1.2$ & 0.0 & 0.0 & 0.0 & $8.0 \pm 1.6$ & 0.0 \\
M2 & $16.0 \pm 1.4$ & 0.0 & 0.0 & 0.0 & $16.0 \pm 1.6$ & 0.0 \\
M3 & $12.0 \pm 0.9$ & $20.0 \pm 0.7$ & $18.0 \pm 0.9$ & 0.0 & $20.0 \pm 1.9$ & $12.0 \pm 1.2$ \\
M4 & 0.0 & $12.0 \pm 0.8$ & 0.0 & $16.0 \pm 1.2$ & 0.0 & 0.0 \\
M5 & $14.0 \pm 1.6$ & 0.0 & $12.0 \pm 0.5$ & $16.0 \pm 1.2$ & $20.0 \pm 0.8$ & 0.0 \\
M6 & 0.0 & $16.0 \pm 1.7$ & 0.0 & 0.0 & $12.0 \pm 1.9$ & 0.0 \\
M7 & $10.0 \pm 1.1$ & 0.0 & 0.0 & 0.0 & 0.0 & 0.0 \\
M8 & 0.0 & 0.0 & $10.0 \pm 0.6$ & 0.0 & $12.0 \pm 2.1$ & 0.0 \\
M9 & $14.0 \pm 1.4$ & 0.0 & $12.0 \pm 1.3$ & 0.0 & $20.0 \pm 0.5$ & 0.0 \\
M10 & 0.0 & $16.0 \pm 2.1$ & 0.0 & 0.0 & 0.0 & 0.0 \\
\hline
\end{tabular}

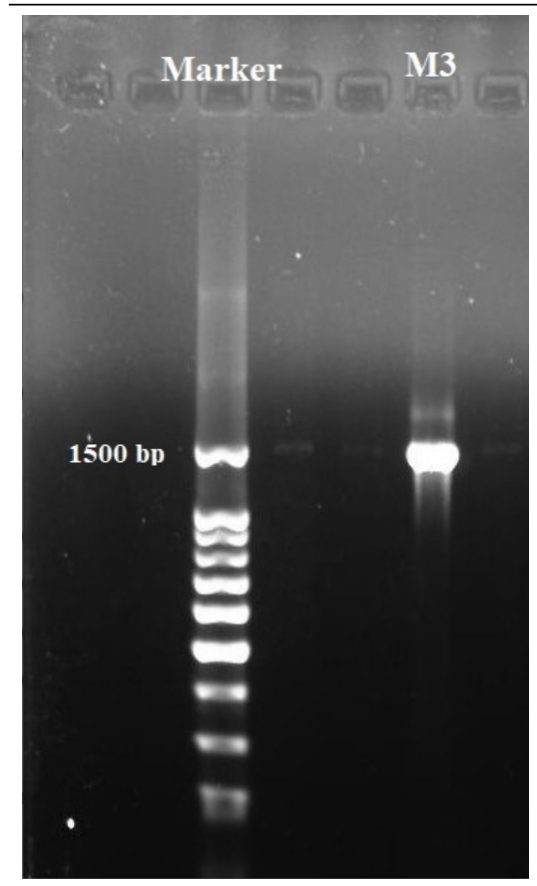

Fig. 5. Agarose gel electrophoreses of the amplified $16 \mathrm{~S}$ rRNA gene of isolate M3. cytotoxic activity against MDA-MB-231 breast cancer cell line ${ }^{49}$.

Molecular phylogeny of the selected isolate

Based on the results obtained, isolate $\mathrm{M} 3$ has been selected for molecular phylogenetic analysis and identification using16S rDNA comparison sequence phylogenetic analysis in order to create phylogenetic and evolutionary organismal relations ${ }^{50}$. Agarose gel electrophoresis (Fig. 5) has been used to detect the produced amplicons from the isolate selected.

The sequencing data utilizing this strategy ( $\mathrm{ABI} 3730 \mathrm{xl}$ ) was 1500 base pair, and it was aligned with other sequences of related actinomycetes on the database to determine its phylogenetic relationship to other actinomycetes. According to $16 \mathrm{~S}$ rRNA gene sequence analysis of isolate M3 compared to Blast search computer-based program which provided the highest homology. The results showed that, the isolate under study was similar to Streptomyces mutabilis with $97 \%$ similarity percentage. The sequence of isolate 
M3 was deposited in Gene-Bank as Streptomyces mutabilis M3 with accession number MT483919, and the phylogenetic tree was constructed as shown in (Fig. 6). The identification of Streptomyces sp. using 16S rRNA revealed that the marine soil samples are predominantly insulated. This result is in line with previous research, where Streptomyces sp. recovery was higher than the other actinobacterial genera with antimicrobial activity ${ }^{51}$. Streptomyces mutabilis sp. MII. which was previously isolated from a sediment sample collected in the Red Sea at the Hurghada Coast has new bioactive compounds and showed good antimicrobial and anticancer activity ${ }^{52}$.

\section{Anticancer activity}

The cytotoxicity of Streptomyces mutabilis M3 MT483919 extract was evaluated toward different human cancer cell lines using MTT assay. Fig. 7 shows the cell viability of the different cancer cell lines after exposure to various concentrations of the extract for $72 \mathrm{~h}$. The extract exhibited a significant reduction in the viability of Mcf7, HepG2 and HCT116 cancer cell lines and the IC50 (concentration that necessary to cause 50\% reduction in cell viability were $324.77,333.31$ and 354.46, respectively. In addition, Streptomyces mutabilis M3 extract altered the morphology of the viable cancer cell lines tested (Fig. 8).

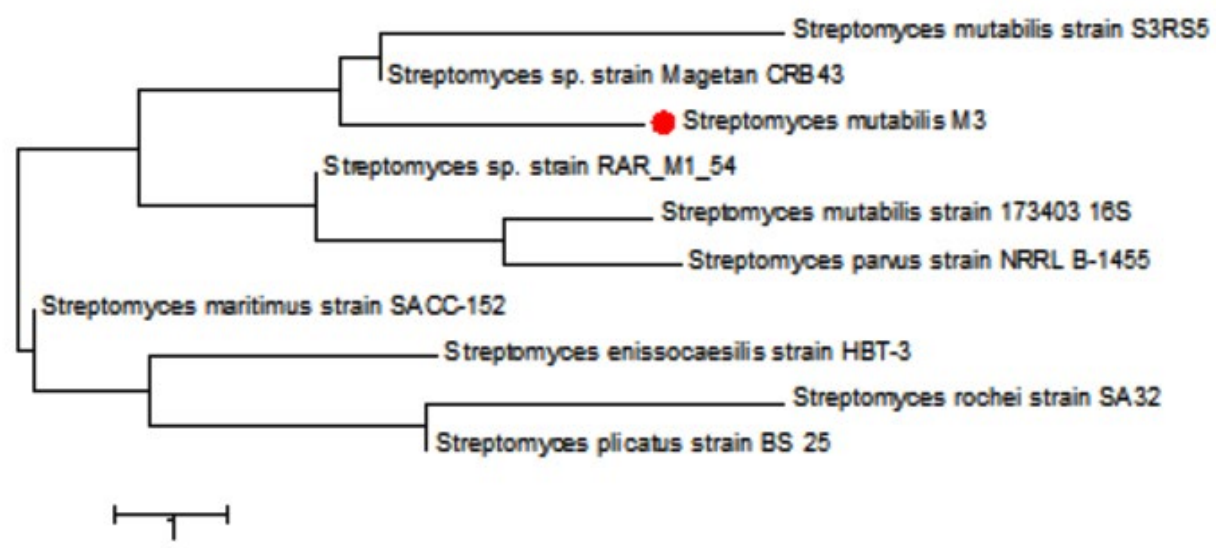

Fig. 6. Phylogenetic tree based on $16 \mathrm{~S}$ rRNA sequences using neighbor joining method showing relationships between the selected $\mathrm{M} 3$ isolate isolated from mangrove habitat and their closely related type strains

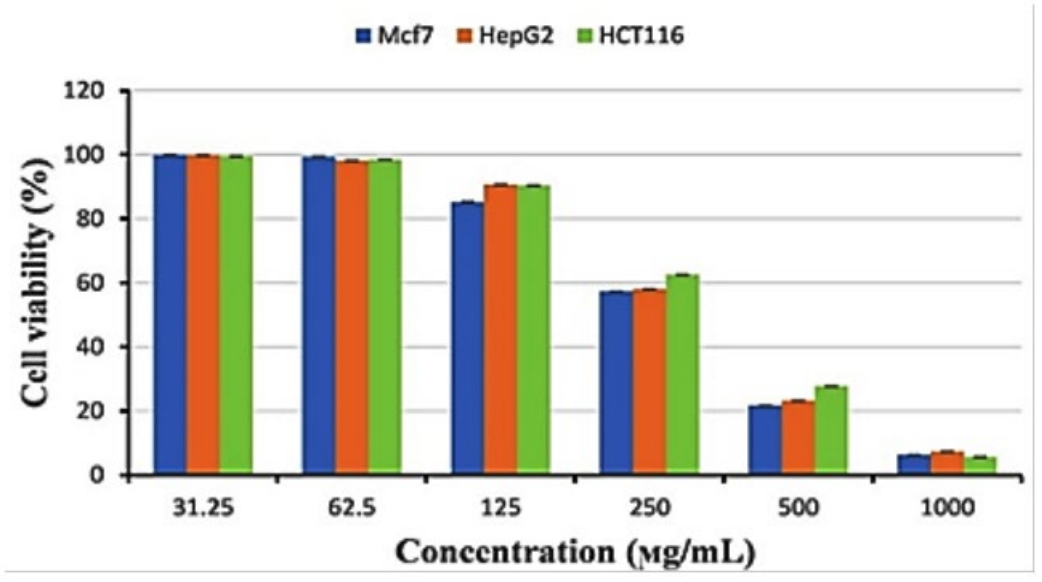

Fig. 7. Cytotoxicity of Streptomyces mutabilis M3 MT483919 extract against breast cancer cell line (Mcf7), liver cancer cell line (HepG2) and colon cancer cell line (HCT116) 
Actinomycetes are rich source of unmatched anticancer compounds specially the Streptomyces because they possess different gene clusters responsible for the manufacture of polyketide and no ribosomal peptide synthases ${ }^{53,54}$. Many studies have confirmed the antitumor activity of different Streptomyces species ${ }^{55}$. The extract of Streptomyces mutabilis $\mathrm{M} 3$ reduced the viability of Mfc7, HepG2 and HCT116 cancer cell lines by more than $90 \%$ at concentration $1000 \mathrm{Mg} / \mathrm{ml}$. These results suggest that the strain produce secondary metabolites with anticancer activity and the purified components of the extract could be more promising in terms of activity and the effective concentration.

\section{Bio-flocculating activity}

Treatment of wastewater is a main research topic worldwide. Flocculation is regarded as amazing way for eliminating pollutants from wastewater as was previously reported ${ }^{56}$. Primarily Streptomyces mutabilis extract showed considerable bio- flocculating activity in kaolin clay treatment (Fig. 9) so that, it had remarkable efficiency when tested as a bio-flocculant producer for treatment of different seawater samples collected from different sites (Ebrahemia, Eastern Harbor and Quit-Bay) along Mediterranean Sea shores, Alexandria, Egypt. The results in Table 5 explained that, Streptomyces mutabilis M3 MT483919 has high bio flocculating activity and the recovery of the samples ranged between 71.97 and 76.05 Similar results were reported by ${ }^{57}$ who reported the promising applications of the bio flocculant QZ-7 synthesized by a novel Bacillus salmalaya strain 139SI in wastewater treatment. Chemical Composition analysis of crude extract Fourier transform infrared (FT-IR) spectral analysis The FT-IR spectrum of antimicrobial substance produced by isolate $\mathrm{M} 3$ showed peaks at $3441.01 \mathrm{~cm}^{-1}, 2669.48 \mathrm{~cm}^{-1}, 2067.69 \mathrm{~cm}^{-1}$, $1635.64 \mathrm{~cm}^{-1}, 1381.03 \mathrm{~cm}^{-1}, 1118.71 \mathrm{~cm}^{-1}$ and $617.22 \mathrm{~cm}^{-1}$, corresponding to the following functional groups such as alcohol $(\mathrm{O}-\mathrm{H})$, alkanes ( $\mathrm{C}$ $\mathrm{H})$, alkene $(\mathrm{C}=\mathrm{C})$, amine $(\mathrm{N}-\mathrm{H})$, alcohol $(\mathrm{O}-\mathrm{H})$, amine (C-N) and halo compound (C-Br), respectively (Fig. 10).

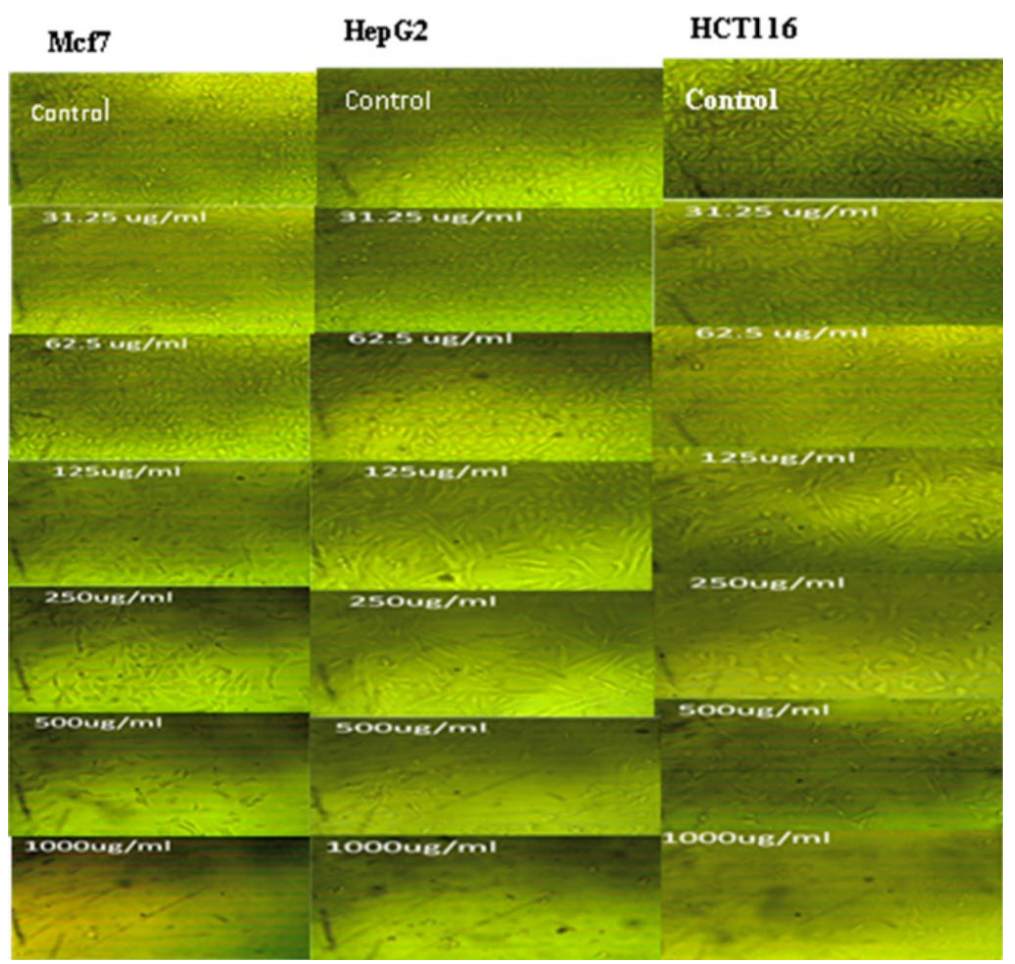

Fig. 8. Morphology of Mfc7, HepG2 and HCt116 cancer cell lines after exposure to different concentrations (0-1000 $\mathrm{Mg} / \mathrm{mL}$ ) of Streptomyces mutabilis M3 MT483919 extract for $72 \mathrm{~h}$ 
Similarly, salim and his team reported absorbance ranging from 3359.18 to 2927.10 $\mathrm{cm}^{-1}$ for the isolate of actinomycetes FA9, corresponding to amine group ${ }^{58}$. A peak of

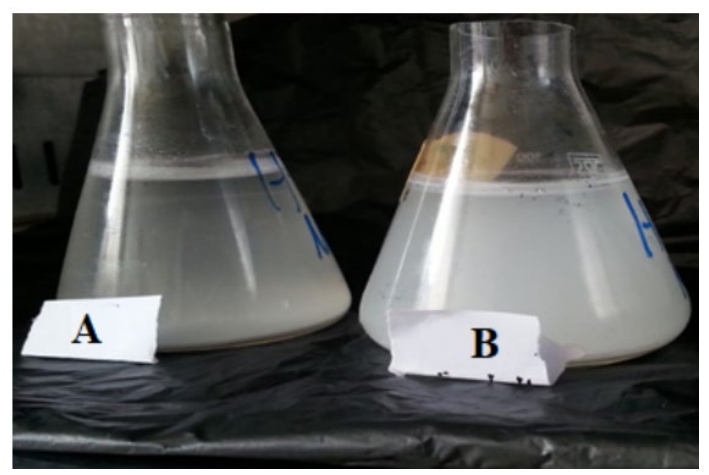

Fig. 9. Bio-flocculant activity by Streptomyces mutabilis M3 MT483919 extract. The sample after treatment (A) and before treatment (control) (B)
$3398 \mathrm{~cm}^{-1}$ characteristic of hydroxyl $(\mathrm{O}-\mathrm{H})$ and 3 common vibration peaks between 2899 and 2977 $\mathrm{cm}^{-1}$ characteristic of (C-H) symmetric (saturated) vibration of hydrocarbon was also recorded in previous study ${ }^{59}$.

\section{GC-MS analysis}

The GC-MS study has been used to classify the bioactive components. A total of 16 peaks are shown in the chromatogram GC-MS of the extract (Fig. 11). The GC-MS crude extract chromatogram identified 17 peaks at various times and retention times. They were found with the use of the NIST database (NIST 11 MS Server and MS Search System v.2.0 g).The active principles with their retention time (RT), molecular formula (MF), Molecular weight (MW) and concentration (\%) are accessible in Table 6. The major compounds were Undecane, 2H-Pyran-3-ol,tetrahydro-2,2,6trimethyl-6-(4-methyl-3-cyclohexen-1-yl)-,[3S-

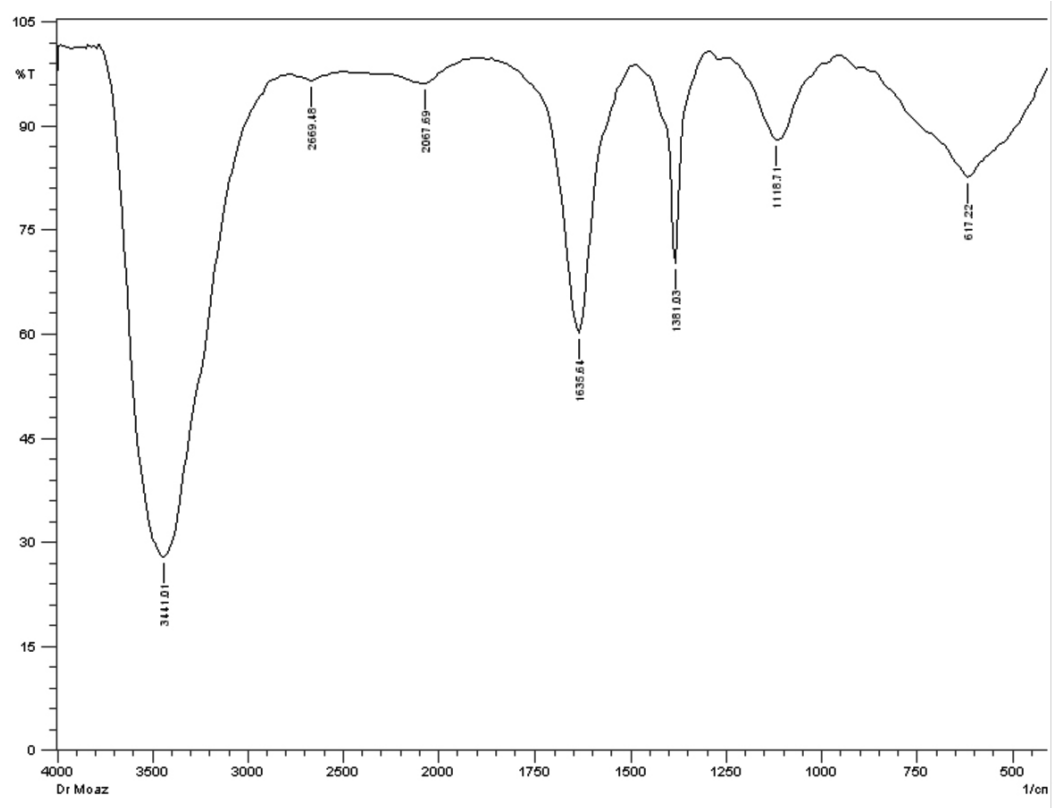

Fig. 10. FT-IR of crude extract of Streptomyces mutabilis M3 MT483919

Table 5. Bio-flocculant activity of Streptomyces mutabilis M3 MT483919 extract for seawater treatment

\begin{tabular}{lccc}
\hline & \multicolumn{2}{c}{ OD at $550 \mathrm{~nm}$} \\
\cline { 2 - 3 } Sea water sample & Before treatment (Control) & After treatment & Bio-floculating activity \% \\
\hline Ebrahemia & 1.645 & 0.394 & 76.05 \\
Eastern Harbor & 1.795 & 0.434 & 75.82 \\
Quit-Bay & 1.905 & 0.534 & 71.97 \\
\hline
\end{tabular}


Table 6. Components detected in Streptomyces mutabilis M3 MT483919 crude extract

\begin{tabular}{|c|c|c|c|c|c|}
\hline No & $\begin{array}{l}\text { R T Value } \\
\text { (In Min.) }\end{array}$ & Compound & $\begin{array}{l}\text { Mol. } \\
\text { Formula }\end{array}$ & $\begin{array}{l}\text { Molecular } \\
\text { Weight }\end{array}$ & $\begin{array}{l}\text { Peak } \\
\text { area }(\%)\end{array}$ \\
\hline 1 & 5.74 & Diisopropylamine & $\mathrm{C}_{6} \mathrm{H}_{15} \mathrm{~N}$ & 101 & 3.10 \\
\hline 2 & 8.81 & Undecane & $\mathrm{C}_{11}^{0} \mathrm{H}_{24}$ & 156 & 30.68 \\
\hline 3 & 14.19 & Ethanol, 2-(diethylamino) & $\mathrm{C}_{6} \mathrm{H}_{15} \mathrm{NO}^{24}$ & 117 & 1.92 \\
\hline 4 & 15.50 & $\begin{array}{l}\text { Acetone, 1-[4- } \\
\text { (dimethylaminoethoxy)phenyl]- }\end{array}$ & $\mathrm{C}_{13}^{0} \mathrm{H}_{19} \mathrm{NO}_{2}$ & 221 & 3.98 \\
\hline 5 & 18.30 & $\begin{array}{l}\text { 1,2-Benzenedicarboxylic acid, } \\
\text { dimethyl ester }\end{array}$ & $\mathrm{C}_{10} \mathrm{H}_{10} \mathrm{O}_{4}$ & 194 & 7.42 \\
\hline 6 & 19.58 & $\begin{array}{l}\text { Benzoic acid, 3-methyl-2- } \\
\text { trimethylsilyloxy-, trimethylsilyl }\end{array}$ & $\mathrm{C}_{14} \mathrm{H}_{24} \mathrm{O}_{3} \mathrm{~S}_{2}$ & 296 & 2.73 \\
\hline 7 & 23.08 & Bisabolol oxide $B$ & $\mathrm{C}_{15} \mathrm{H}_{26} \mathrm{O}_{2}$ & 238 & 2.23 \\
\hline 8 & 23.56 & 9,12 -octadecadienoic acid & $\mathrm{C}_{27}^{13} \mathrm{H}_{54}^{26} \mathrm{O}_{4}^{2} \mathrm{Si}_{2}$ & 498 & 2.48 \\
\hline 9 & 23.71 & Z,Z,Z-1,4,6,9-Nonadecatetraene & $\mathrm{C}_{19} \mathrm{H}_{32}$ & 260 & 1.26 \\
\hline 10 & 25.09 & $\begin{array}{l}\text { 2H-Pyran-3-ol, tetrahydro-2,2,6- } \\
\text { trimethyl-6-(4-methyl-3-cyclohexen- } \\
\text { 1-yl)-, [3S-[3alpha,6alpha(R)]]- }\end{array}$ & $\mathrm{C}_{15}^{19} \mathrm{H}_{26}^{32} \mathrm{O}_{2}$ & 238 & 11.48 \\
\hline 11 & 27.02 & $9,12,15$-octadecatrienoic a & $\mathrm{C}_{27} \mathrm{H}_{52} \mathrm{O}_{4} \mathrm{Si}_{2}$ & 496 & 2.06 \\
\hline 12 & 28.89 & Hexadecanoic acid, methyl & $\mathrm{C}_{17}^{21} \mathrm{H}_{34} \mathrm{O}_{2}^{4}$ & 270 & 7.52 \\
\hline 13 & 32.10 & $\begin{array}{l}\text { 11,14-Octadecadienoic acid, methyl } \\
\text { ester }\end{array}$ & $\mathrm{C}_{19} \mathrm{H}_{34} \mathrm{O}_{2}$ & 294 & 6.70 \\
\hline 14 & 32.22 & 9-Octadecenoic acid (Z)-, methyl ester & $\mathrm{C}_{19} \mathrm{H}_{36} \mathrm{O}_{2}$ & 296 & 10.86 \\
\hline 15 & 32.71 & Cyclopropanebutanoic acid & $\mathrm{C}_{25} \mathrm{H}_{42}^{30} \mathrm{O}_{2}^{2}$ & 374 & 1.46 \\
\hline 16 & 39.75 & $\begin{array}{l}\text { 1-Monolinoleoylglycerol } \\
\text { trimethylsilyl ether }\end{array}$ & $\mathrm{C}_{27} \mathrm{H}_{54} \mathrm{O}_{4} \mathrm{Si}_{2}$ & 498 & 2.67 \\
\hline
\end{tabular}

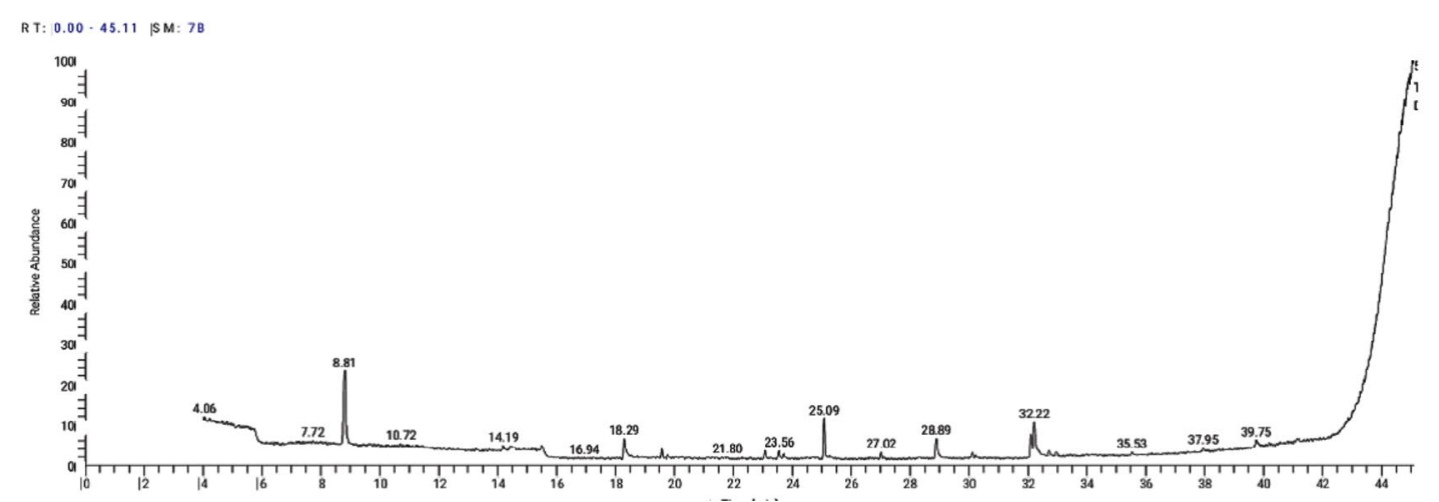

Fig. 11. GC-MS chromatogram and structure formulas of compounds of the bioactive compounds extracted from Streptomyces mutabilis M3 MT483919

[3alpha,-6alpha (R)]] and 9-Octadecenoic acid (Z)- methyl ester with Peak area percentage 30.68, 11.48 and $10.86 \%$, respectively.

Many of the compounds found have shown interesting biological activities ${ }^{60}$. Antibacterial activity is reported to be caused by hexadecanoic acid, octadecanic acid and tetradecanoic acid ${ }^{61}$. Octadecanoic acid collected from neem extract was examined against Salmonella sp., S. aureus and $E$. coli) and showed good inhibition activity against $S$. aureus than E. coli and Salmonella spp. ${ }^{62}$. Selvin and his team observed hexadecanoic acid and hexadecanoic acid methyl ester from actinomycetes isolate Nocardiopsisda ssonvillei MAD08 by using GC-MS analysis ${ }^{63}$. The basic components of GC-MS from Cytosoriacompressa 
are the fatty acids (hexadecanoic and octadecanoic acid) and fatty acid esters (hexadecanoic hydroxy ester and hexadecanic acids) ${ }^{64}$. A novel Streptomyces isolate Chy 2-3 isolated from chyulu National Park produced bioactive metabolites was identified as Octadecanoic acid that has antifungal, antitumor and antibacterial activity ${ }^{65}$.

\section{CONCLUSION}

In conclusion, reasonable numbers of actinomycetes isolates were successfully isolated from mangrove collected from $17 \mathrm{~km}$ south of the Egyptian Red Sea coast town of Safaga. Some of the isolates investigated showed wide range of antimicrobial activity against the tested indicator pathogenic bacteria. Future research including study of valuable biotechnological applications of the extracted active metabolites will be conducted.

\section{ACKNOWLEDGMENTS}

We are grateful to the management of the NIOF Red Sea Branch and Field Strategy Trips for the studying of mangrove environment and biodiversity project.

\section{CONFLICT OF INTEREST}

The authors declare that there is no conflict of interest.

\section{AUTHORS' CONTRIBUTION}

All authors listed have made a substantial, direct and intellectual contribution to the work, and approved it for publication.

\section{FUNDING}

This study was supported by the National institute of Oceanography and Fishers, Egypt, fund via 2019 Research Plans Support Program.

\section{DATA AVAILABILITY}

The data used to support the findings of this study are available from the corresponding authors upon request.

\section{ETHICS STATEMENT}

This article does not contain any studies with human participants or animals performed by any of the author.
1.

Li F, Liu S, Lu Q, et al. Studies on antibacterial activity and diversity of cultivable actinobacteria isolated from mangrove soil in Futian and Maoweihai of China. Based Complement and Alternat Med. 2019;2019. doi: 10.1155/2019/3476567

2. Dawes C. Marine Botany. JohnWiley\&Sons. New York, NY, USA. 1981;160.

3. Rajkumar J, Swarnakumar N, Sivakumar K, Thangaradjou, T, Kannan L. Actinobacterial diversity of mangrove environment of the Bhitherkanika mangroves, east coast of Orissa, India. International Journal of Scientific and Research Publications. 2012;2:1-6.

4. Abd El-Wahab E. Autecology and Conservation Considerations of Avicennia marina (Forsk.) Vierh. in the Gulf of Aqaba, Egypt, M. Sc. Thesis, Faculty of Science, Zagazig University, Zagazig. 2004.

5. Sathya R, Ushadevi T. Industrially important enzymes producing streptomyces species from mangrove sediments. Int J Pharm Pharm Sci. 2014;6:233-237.

6. Law JWF, Ser HL, Khan TM, et al. Streptomyces colonosanans sp. nov., a novel actinobacterium isolated from Malaysia mangrove soil exhibiting antioxidative activity and cytotoxic potential against human colon cancer cell lines. Front Microbiol. 2017;8:877. doi: 10.3389/fmicb.2017.00877

7. Tiwari K, Gupta RK. Diversity and isolation of rare actinomycetes: an overview. Critical Rev Microbiol. 2013;39(3):256-294. doi: 10.3109/1040841X.2012.709819

8. Lee LH, Zainal N, Azman AS, et al. Streptomyces pluripotens sp. nov., a bacteriocin-producing streptomycete that inhibits meticillin-resistant Staphylococcus aureus. Int I Syst Evol Microbiol. 2014;64(Pt 9):3297-3306. doi: 10.1099/ijs.0.065045-0

9. Fu PC, Zhang YZ, Geng HM, Chen SL. The complete chloroplast genome sequence of Gentiana lawrencei var. farreri (Gentianaceae) and comparative analysis with its congeneric species. Peer J. 2016;4:e2540. doi: 10.7717/peerj.2540

10. Madkour HA, Mohammed AW, . Nature and geochemistry of surface sediments of the mangrove environment along the Egyptian Red Sea coast. Environ Geol. 2008;54:257-267. doi: 10.1007/s00254-0070813-8

11. Hasan MH. Destruction of sea cucumber populations due to overfishing at Abu Ghosoun area, Red Sea. J Basic Appl Zool. 2019;80:5. doi: 10.1186/s41936-0190074-6

12. Rice EW, Baird RB, Eaton AD, Clesceri LS. Standard methods for the examination of water and wastewater. (American Public Health Association Washington, DC. USA. 2012;10.

13. Strickland J, Parsons T. Bull. Fish. Res. Bd Can. A practical handbook of seawater analysis. 1968;311.

14. Koroleff F, Grasshoff K. Methods of seawater analysis. GRASSHOFF, K. ed. 1976.

15. Retnowati $Y$, Sembiring L, Moeljopawiro S, Djohan TS, Soetarto ES. Diversity of antibiotic-producing actinomycetes in mangrove forest of Torosiaje, Gorontalo, Indonesia. Biodiversitas J Biol Div. 2017;18:1453-1461. 
16. Bensultana A, Ouhdouch Y, Hassani L, Mezrioui NE, Rafouk L. Isolation and characterization of wastewater sand filter actinomycetes. World J Microbiol Biotechnol. 2010;26:481-487. doi: 10.1007/s11274-009-0194-0

17. Bawazir AMA, Shivanna GB, Shantaram M. Ipact of different media for growth and production of different pigments in actinomycetes isolated from soils of Hadhramout, YEMEN. Eur J Biomed. 2018;5:615-619.

18. Maria A, Sharmili A, Anbumalarmathi J. Isolation and characterization of actinomycetes from marine soil. MOJ Biol Med. 2018;3:221-225.

19. Marshall KC, Alexander M. Growth characteristics of fungi and actinomycetes. J Bacteriol. 1960;80(3):412416. doi: $10.1128 / J B \cdot 80.3 .412-416.1960$

20. Krassilnikov $\mathrm{N}$, Koreniako $\mathrm{A}$. The bactericidal substance of the actinomycetes. Microbiol. 1939;8:673-685.

21. Jiang $\mathrm{Y}, \mathrm{Li} \mathrm{Q}, \mathrm{Chen} \mathrm{X}$, Jiang, C. Isolation and cultivation methods of Actinobacteria. Actinobacteria-basic Biotechnol Appll. 2016;39-57. doi: 10.5772/61457

22. Kumar RR, Jadeja VJ. Isolation of actinomycetes: A complete approach. Int J Curr Microbiol Appl Sci. 2016;5(5):606-618. doi: 10.20546/ ijcmas.2016.505.062

23. Chaudhary HS, Yadav J, Shrivastava AR, Singh S, Singh AK, Gopalan N. Antibacterial activity of actinomycetes isolated from different soil samples of Sheopur (A city of central India). J Advanced pharma Technol Res. 2013;4(2):118-123. doi: 10.4103/2231-4040.111528

24. Remya M, Vijayakumar R. Isolation and characterization of marine antagonistic actinomycetes from west coast of India. Medicine Biol. 2008;15:13-19.

25. Priyanka S, Jayashree M, Shivani R, Anwesha S, Rao KB. Characterisation and identification of antibacterial compound from marine actinobacteria: In vitro and in silico analysis. J Infect Public Health. 2019;12(1):83-89. doi: 10.1016/j.jiph.2018.09.005

26. Malek NA, Zainuddin Z, Chowdhury AJK, Abidin ZAZ. Diversity and antimicrobial activity of mangrove soil actinomycetes isolated from Tanjung Lumpur, Kuantan. J Teknol. 2015;77(25):37-43. doi: 10.11113/jt.v77.6734

27. Jayasudha J, Kumar G, Karthik L, Bhaskara Rao K. Biological control of vibriosis by antagonistic actinobacteria-an in vitro study. J Agricul Technol. 2011;7:271-280.

28. Wilson $\mathrm{KH}$, Blitchington RB, Greene RC. Amplification of bacterial $16 \mathrm{~S}$ ribosomal DNA with polymerase chain reaction. J Clinic microbiol. 1990;28(9):1942-1946. doi: 10.1128/JCM.28.9.1942-1946.1990

29. Slater T, Sawyer B, Strauli U. Studies on succinatetetrazolium reductase systems: III. Points of coupling of four different tetrazolium salts III. Points of coupling of four different tetrazolium salts. Biochim Biophysica Acta. 1963;77:383-393. doi: 10.1016/00063002(63)90513-4

30. Van de Loosdrecht A, Beelen R, Ossenkoppele G, Broekhoven M, Langenhuijsen MA. A Tetrazoliumbased colorimetric MTT assay to quantitate human monocyte mediated cytotoxicity against leukemic cells from cell lines and patients with acute myeloid leukemia. J immunol Methods. 1994;174(1-2):311-320. doi: 10.1016/0022-1759(94)90034-5

31. Alley MC, Scudiero DA, Monks A, et al. Feasibility of drug screening with panels of human tumor cell lines using a microculture tetrazolium assay. Cancer Res. 1988;48:589-601.

32. Kurane R, Hatamochi K, Kakuno T, Kiyohara M, Hirono $M$, Taniguchi Y. Production of a bioflocculant by Rhodococcus erythropolis S-1 grown on alcohols. Biosci Biotechnol Biochem. 1994;58(2):428-429. doi: 10.1271/bbb.58.428

33. Ravi L, Kannabiran K. Extraction and Identification of gancidin W from marine Streptomyces sp. VITLGK012. Indian J Pharma Sci. 2018;80:1093-1099.

34. Gnanavel V, Saral AM. GC-MS analysis of petroleum ether and ethanol leaf extracts from Arbus precatorius linn. Int J Pharm Bio Sci. 2013;4(3):37-44.

35. Belal AAM, Kelany MS, Hamed MM, Abd El-Fattah LS. Selected bacterial communities associated with macro-benthic fauna assemblages at the Timsah Lake and the Western Lagoon's sediments, Suez Canal, Egypt. Egypt J Aquatic Res. 2020;46(2):137-143. doi: 10.1016/j.ejar.2020.02.003

36. Xu DB, Ye WW, Han Y, Deng ZX, Hong K. Natural products from mangrove actinomycetes. Mar Drugs. 2014;12(5):2590-2613. doi: 10.3390/md12052590

37. Sun C, Li F, Cai Z, Wu L. Brief introduction of mangrove researches including drug discovery granted by National Natural Science Foundation of China from 1986 to 2016. Chin J Antibiot. 2017;2:241-248.

38. Rosmine E, Varghese SA. Isolation of actinomycetes from mangrove and estuarine sediments of Cochin and screening for antimicrobial activity. J Coastal Life Med. 2016;4:207-210. doi: 10.12980/jclm.4.2016j5-148

39. Beltagy E, Abdel-Shakour S, Qari S H, Reffat B. Diversity and antimicrobial activity of Red Sea mangrove actinomycetes (Egypt). Int J Environ Sci Eng. 2015;6:5974 .

40. Isik K, Gencbay T, Ozdemir-Kocak F, Cil E. Molecular identification of different actinomycetes isolated from East Black Sea region plateau soil by $16 \mathrm{~S}$ rDNA gene sequencing. Afr J Microbiol Res. 2014;8(9):878-887. doi: 10.5897/AJMR2013.6174

41. Das S, Lyla P, Khan SA. Distribution and generic composition of culturable marine actinomycetes from the sediments of Indian continental slope of Bay of Bengal. Chin J Ocean Limnol. 2008;26:166-177. doi: 10.1007/s00343-008-0166-5

42. Selyanin V, Oborotov G, Zenova G, Zvyagintsev D. Alkaliphilic soil actinomycetes. Microbiol. 2005: 74:729-734. doi: 10.1007/s11021-005-0131-7

43. Abd-Elnaby HM, Abo-Elala GM, Abdel-Raouf UM, Hamed MM. Distribution and characterization of Actinomycetes in Suez Bay sediments. Egypt Asian J Appl Sci. 2016;4.

44. Rabeh SA, Azab EA, Aly MM. Studies on bacterioplankton and inhibitory strains of aquatic actinomycetes in Lake Bardawil, Egypt. World J Microbiol Biotechnol. 2007;23:167-176. doi: 10.1007/s11274-006-9206-5

45. Walter SRS. Jaekel U, Osterholz, H, et al. Microbial decomposition of marine dissolved organic matter in cool oceanic crust. Nat Geosci. 2018;11:334-339. doi: 10.1038/s41561-018-0109-5

46. Hirsch AM, Valdes M. Micromonospora: An important microbe for biomedicine and potentially for biocontrol 
and biofuels. Soil Biol Biochem. 2010;42:536-542. doi: 10.1016/j.soilbio.2009.11.023

47. Deepthi A, Rosamma P. Actinomycete isolates from Arabian Sea and Bay of Bengal: biochemical, molecular and functional characterization, Cochin University of Science And Technology. 2014.

48. Tan LTH, Chan KG, Pusparajah P, et al. Mangrove derived Streptomyces sp. MUM265 as a potential source of antioxidant and anticolon-cancer agents. BMC Microbiol. 2019;19(1):38. doi: 10.1186/s12866019-1409-7

49. Abdelfattah MS, Elmallah MIY, Hawas UW, El-Kassema LTA, Eid MAG. Isolation and characterization of marinederived actinomycetes with cytotoxic activity from the Red Sea coast. Asian Pacific J Tropical Biomed. 2016;6(8):651-657. doi: 10.1016/j.apjtb.2016.06.004

50. Sharma M, Dangi P, Choudhary M. Actinomycetes: source, identification, and their applications. Int J Curr Microbiol App Sci. 2014;3:801-832.

51. Dasn R, Romi W, Das R, Sharma HK, Thakur D. Antimicrobial potentiality of actinobacteria isolated from two microbiologically unexplored forest ecosystems of Northeast India. BMC Microbiol. 2018;18:71. doi: 10.1186/s12866-018-1215-7

52. Hamed A, Abdel-Razek AS, Frese M, et al. Acetylborrelidin B: a new bioactive metabolite from Streptomyces mutabilis sp. MII. Z Naturforsch C. 2018;73:49-57. doi: 10.1515/znc-2017-0140

53. Lopez-Lazaro MM, Pastor N, Azrak SS, Ayuso MJ, Austin CA, Cortes F. Digitoxin inhibits the growth of cancer cell lines at concentrations commonly found in cardiac patients. J Nat Prod. 2005;68(11):1642-1645. doi: 10.1021/np050226l

54. Aftab U, Zechel DL, Sajid I. Antitumor compounds from Streptomyces sp. KML-2, isolated from Khewra salt mines, Pakistan. Biol Res. 2015;48:58. doi: 10.1186/ s40659-015-0046-3

55. Hussain A, Rather MA, Dar MS, et al. Streptomyces puniceus strain AS13., Production, characterization and evaluation of bioactive metabolites: A new face of dinactin as an antitumor antibiotic. Microbiol Res. 2018;207:196-202. doi: 10.1016/j.micres.2017.12.004

56. Agunbiade MO, Pohl CH, Ashafa AO. A Review of the Application of Biofloccualnts in Wastewater Treatment. Polish J Environ Studies. 2016;25(4):1381-
1389. doi: $10.15244 /$ pjoes/61063

57. Abu Tawila, ZM, Ismail S, Dadrasnia A, Usman MM. Production and characterization of a bioflocculant produced by Bacillus salmalaya 139SI-7 and its applications in wastewater treatment. Molecules. 2018;23(10):2689. doi: 10.3390/molecules23102689

58. Salim FM, Sharmili SA, Anbumalarmathi J, Umamaheswari K. Isolation, molecular characterization and identification of antibiotic producing actinomycetes from soil samples. J Appl Pharma Sci. 2017;7:069-075.

59. Priya AJ, Sagadevan E, Arumugam. Detection of antioxidant and antimicrobial activities in marine actinomycetes isolated from Puducherry coastal region. J Modern Biotechnol. 2012;1:63-69.

60. Belakhdar G, Benjouad A, Abdennebi E. Determination of some bioactive chemical constituents from Thesium humile Vahl. J Mater Environ Sci. 2015;6:2778-2783.

61. Agoramoorthy G, Chandrasekaran M, Venkatesalu V, Hsu M. Antibacterial and antifungal activities of fatty acid methyl esters of the blind-your-eye mangrove from India. Brazilian J Microbiol. 2007;38(4):739-742. doi: 10.1590/S1517-83822007000400028

62. Pu ZH, Zhang $Y-Q$, Yin Z-Q, et al. Antibacterial activity of 9-octadecanoic acid-hexadecanoic acidtetrahydrofuran-3, 4-diyl ester from neem oil. Agricul Sci China. 2010;9(8):1236-1240. doi: 10.1016/S16712927(09)60212-1

63. Selvin J, Shanmughapriyan S, Gandhimathi R, et al. Optimization and production of novel antimicrobial agents from sponge associated marine actinomycetes Nocardiopsis dassonvillei MAD08. Appl Microbiol Biotechnol. 2009;83(3):435-445. doi: 10.1007/s00253009-1878-y

64. Abou-Elela GM, Abd-Elnaby H, Ibrahim HA, Okbah $M$. Marine natural products and their potential applications as anti-infective agents. World App/ Sci J. 2009;7:872-880.

65. Karanja E, Boga $H$, Muigai A, Wamunyokoli $F$, Kinyua J, Nonoh J. "Growth characteristics and production of secondary metabolites from selected novel Streptomyces species isolated from selected Kenyan national parks," in Proceedings of the 5th JKUAT Scientific, Technological and Industrialization Conference (Juja: Jomo Kenyatta University of Agriculture and Technology). 2010;51-80. 